\title{
Zooplankton distribution and dynamics in a temperate shallow estuary
}

\author{
Sónia Cotrim Marques - M. A. Pardal - M. J. Pereira · F. Gonçalves · \\ J. C. Marques · U. M. Azeiteiro
}

(C) Springer Science+Business Media B.V. 2007

\begin{abstract}
The spatial, temporal and tidal dynamics of the zooplanktonic community of the Mondego estuary was studied from January 2003 to 2004. The monthly sampling procedure included the measurement of hydrological parameters (salinity, temperature, Secchi transparency, chlorophyll $a$ and nutrients) and the collection of zooplankton with a Bongo net of $335 \mu \mathrm{m}$ mesh size. Zooplankton composition, distribution, density, biomass and diversity were determined. The principal component analysis (PCA) revealed the existence of a spatial gradient with the upstream sampling stations, associated to high values of nutrients, in opposition to the downstream stations characterized by higher salinity and transparency values. The Copepoda was the main dominant group and Acartia tonsa revealed to be the more abundant taxon. The spatial and
\end{abstract}

Guest editors: M. J. Costa, H. Cabral \& J. L. Costa Towards an integrated knowledge and management of estuarine systems

S. C. Marques $(\bowtie) \cdot$ M. J. Pereira · F. Gonçalves Department of Biology, University of Aveiro, Aveiro 3810-193, Portugal

e-mail: scotrim@ci.uc.pt

S. C. Marques - M. A. Pardal - J. C. Marques ·

U. M. Azeiteiro

IMAR - Institute of Marine Research, Department of Zoology, University of Coimbra, Coimbra 3004-517, Portugal temporal dynamics of zooplanktonic communities analysed by non-metric MDS showed the existence of four assemblages of species-sites, reflecting differences in zooplankton composition between both branches of the estuary. The results suggest that abundance, biomass and diversity of the zooplanktonic community are strongly influenced by the hydrological circulation pattern and by direct or indirect human impacts that occur in each branch. The northern branch is dominated by the river flow suffering from regular dredging activities and the southern branch is dominated by tidal circulation suffering from an ongoing eutrophication process.

Keywords Zooplankton - Tidal dynamics · Community structure - Temperate estuary

\section{Introduction}

Coastal and estuarine environments are among the most productive ecological systems on Earth and are recognized as extremely important to human society and, very attractive for transport purposes and also for human settlement (De Jonge et al., 2002). In temperate zones, they support large fisheries, aquaculture, tourism and recreation activities, as well as intense agriculture on their watersheds (Gilabert, 2001). The increases of agricultural practices that include more 
efficient drainage systems promote the increase of nutrient enriched water run-off to coastal waters. These features will enhance primary productivity leading ultimately to eutrophication (De Jonge et al., 2002; Nedwell \& Rafaelli, 1999). Through time, these changes will most probably be reflected at other trophic levels (Cardoso et al., 2004; Pardal et al., 2004). Similar to many other estuaries, the Mondego, Portugal, has undergone significant eutrophication due to organic enrichment (Cardoso et al., 2004; Pardal et al., 2000). Estuarine ecosystems are very dynamic systems where water circulation and land influence (e.g. rivers, sewage flow) induce high variability on the distribution and structure of planktonic populations. Because the unusually dynamic condition experienced in estuaries, such as the Mondego, the zooplankton distribution in these ecosystems is, therefore, spatially and temporally heterogeneous when compared to other aquatic ecosystems, (e.g. Kennish, 1990; Omori \& Ikeda, 1984). In addition, anthropogenic influences may contribute to enhancing natural trends, both directly and indirectly. Although several studies have focused on the zooplankton of the southern branch of the Mondego estuary during the last years (Azeiteiro et al., 1999; Gonçalves et al., 2003; Vieira et al., 2003) a lack of knowledge about the assemblages in the northern branch and a clearly comparative analysis of the communities of both contrasting arms, with different hydrographical conditions, seems to be missing. The aims of the present study, therefore, were: (a) to describe the spatial, temporal and tidal dynamics of the zooplankton communities and (b) to compare the community structure of the zooplankton in the two contrasting branches on tidal, temporal and longitudinal scales.

\section{Materials and methods}

Study site

The Mondego estuary is a warm temperate system, located on the western coast of Portugal $\left(40^{\circ} 08^{\prime} \mathrm{N}, 8^{\circ} 50^{\prime} \mathrm{W}\right)$. It comprises two branches, northern and southern, separated by the Murraceira Island (Fig. 1). The two branches exhibit different hydrographic characteristic: the northern branch which present a low residence time ( $<1$ day), is deeper (4-8 $\mathrm{m}$ during high tide), constitute the main navigation channel, is the location of the Figueira da Foz harbour and suffer from regular dredging activity. The southern branch is shallower ( $2-4 \mathrm{~m}$ deep, during high tide) with higher residence time (2-8 days). It is almost silted up in the upstream areas and as a result the freshwater outflow occurs mainly via the northern branch (Marques et al., 2002).

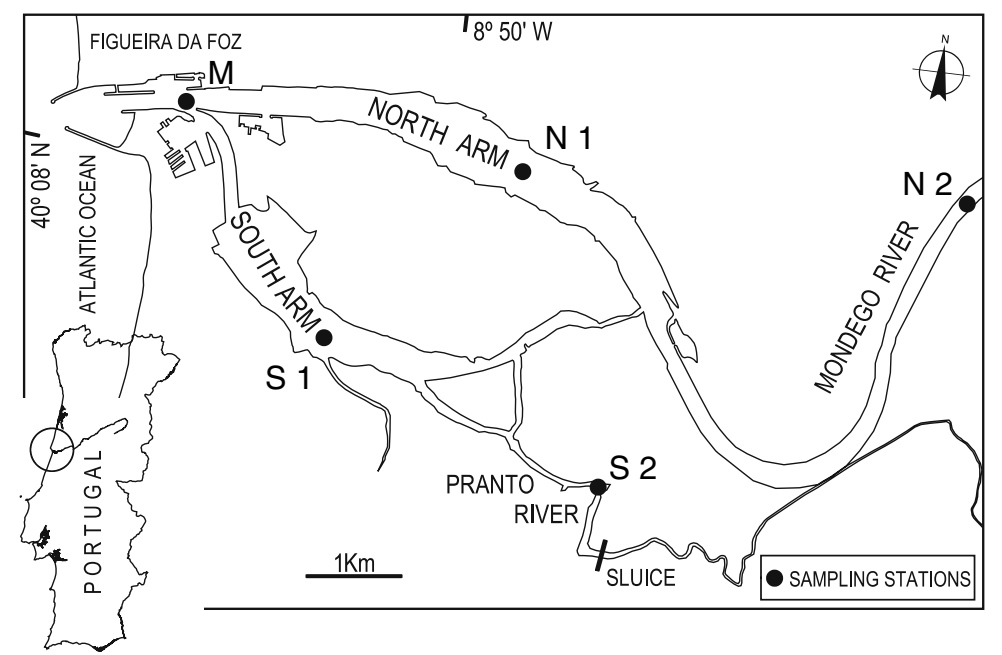

Fig. 1 Map of the Mondego Estuary, Western Portugal, with indication of the sampling stations (M, Mouth, S1 and S2, southern branch, N1 and N2, northern branch) 
Consequently, the water circulation in the southern branch is mostly due to tides and the freshwater input from a small tributary, the Pranto River. The freshwater discharge of this river is controlled by a sluice that is regulated according to the water needs of rice fields in the Mondego Valley (Cardoso et al., 2004; Pardal et al., 2000).

Field sampling and laboratorial procedures

The Mondego estuary was surveyed monthly from January 2003 to 2004 at five sampling stations (M: mouth of the estuary; S1 and S2: southern branch; N1 and N2: northern branch), located on both contrasting branches, in order to have a maximum area coverage of the system (Fig. 1). At each sampling station, sub-surface zooplankton samples were taken at both high and low tides, with a Bongo net with $0.5 \mathrm{~m}$ diameter, $335 \mu \mathrm{m}$ mesh and fixed in $4 \%$ buffered formaldehyde. The volume of water filtered by the nets was estimated with a Hydro-Bios Flowmeter mounted in the mouth of the net. Hydrological parameters such as salinity, temperature and Secchi transparency were measured in situ. Surface water samples were taken to determine nutrient concentrations (nitrates, ammonia and phosphates) and chlorophyll $a$ (Chl- $a$ ).

Zooplanktonic subsamples were obtained for biomass estimation and numerical abundance using a Folsom plankton splitter (Bourdillion, 1964). Zooplankton biomass was determined as ash free dry weight (AFDW) after oven drying at $60^{\circ} \mathrm{C}$ for $72 \mathrm{~h}$ and combustion at $450^{\circ} \mathrm{C}$ for $8 \mathrm{~h}$.

Data analysis

A Principal Component Analysis (PCA) was applied to the environmental parameters using the statistical program CANOCO version 4.0 (Ter Braak \& Smilaeur, 1998), to identify the major sources of variability in the environmental descriptors (Ter Braak, 1995), permitting an assessment of the importance of spatial and temporal variability.

Concerning biodiversity, the number of species was estimated for each station and zooplankton abundance was used to compute heterogeneity according to the Shannon-Wiener index $\left(\mathrm{H}^{\prime}\right)$ (Zar, 1996). Multi-Dimensional Scaling (MDS) ordination was performed in order to define spatial and temporal dynamics of the zooplankton community along the estuary (Clarke \& Gorley, 2001), following the Bray-Curtis similarity index on squared root data transformation (Clarke \& Warwick, 2001). The MDS analyses of similarity between taxa were computed using standardized abundance values and $\log (\mathrm{x}+1)$ transformed data. In order to define ecological distinct groups in zooplankton assemblages and to examine differences in community composition at temporal and spatial scales, multivariate statistics were performed on seasonal data, which were estimated by averaging the monthly values.

\section{Results}

Environmental parameters

In regards to the hydrological data obtained in this study, temperature varied from 8.7 to $23.9^{\circ} \mathrm{C}$, reaching minimum and maximum values during winter and summer, respectively. Considering the salinity, values ranged from 0 to 34.5 observed in January and May, respectively. The values were higher at the downstream stations and in the spring-summer months. The secchi transparency showed an increase from the upstream to the downstream stations, in both branches. Nitrates and phosphates concentrations showed higher values associated with the upstream stations, varying between a minimum of $0.024 \mathrm{mg} \mathrm{l}^{-1}$ in May to a maximum of $1.280 \mathrm{mg} \mathrm{l}^{-1}$ in November, and $0.002 \mathrm{mg} \mathrm{l}^{-1}$ in May to $0.084 \mathrm{mg} \mathrm{l}^{-1}$ in January, respectively. During this study Chl $a$ concentration ranged from $0.66 \mathrm{mg} \mathrm{m}^{-3}$ in February to $55.00 \mathrm{mg} \mathrm{m}^{-3}$ in May. The maximum Chl $a$ concentrations were observed at the upstream stations. The minimum and maximum values of ammonia concentration were found both in May and ranged from 0.002 to $0.590 \mathrm{mg} \mathrm{l}^{-1}$. The downstream stations reached the greatest values, particularly the southern branch. In the PCA (Fig. 2), all stations in the winter months were characterized by higher concentrations of nitrates and phosphates. These stations are located in the 


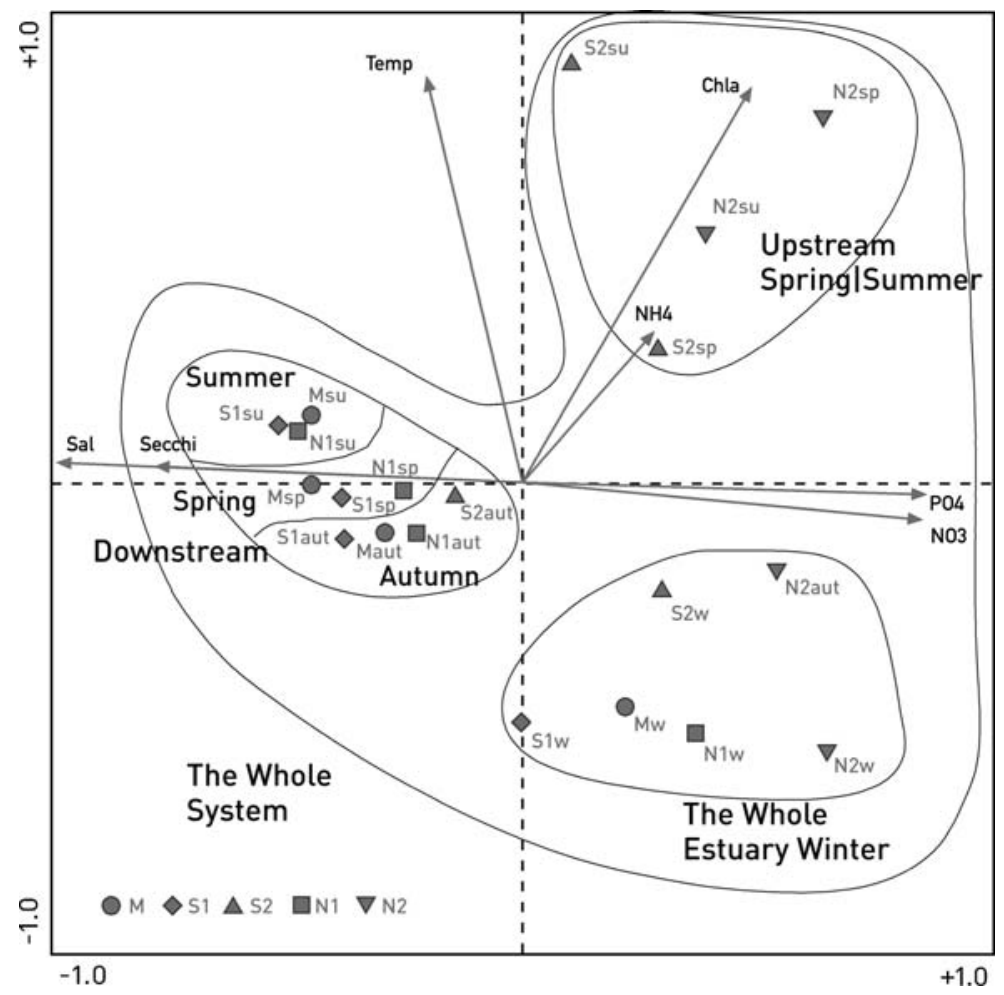

Fig. 2 Results of PCA analysis. Principal component 1 and 2 plot for environmental variables and stations. Temp, temperature; Chl- $a$, chlorophyll $a$; $\mathrm{NH}_{4}$, ammonia; $\mathrm{PO}_{4}$, phosphates; $\mathrm{NO}_{3}$, nitrates; Sal, salinity

right side of the plot, opposite to salinity and transparency. The majority of the winter observations are also situated on the lower right quadrant of the plot, on the opposite side of the temperature vector and associated with lower levels of Chl $a$ and ammonia. With few exceptions, the upstream stations, in spring, summer and autumn, were characterized by higher temperature and Chl $a$ values. Otherwise, downstream stations during that period presented higher salinity and water transparency and were associated with lower levels of nutrients concentrations and Chl $a$. Therefore, the spatial gradient was associated with principal component 1 (salinity and transparency) and the temporal gradient was associated with principal component 2 (temperature and chlorophyll $a$ ).

Zooplankton species composition and abundance

Total zooplankton abundance was highly variable within the study period, at both high and low tide, with no evidence of clear seasonality (Fig. 3). Differences were found in zooplankton abundance found that on the southern branch stations (max. 2,459 in $\mathrm{dm}^{-3}$ ) compared with northern branch stations (max. 1,104 in $\mathrm{dm}^{-3}$ ). Figure 3 shows also that, in intermediate stations (S1 and $\mathrm{N} 1$ ), values of abundance were particularly higher at low tide. Otherwise, in the extreme stations (M, S2 and N2) a clear pattern is not so evident, probably depending on the dynamics of river discharge and tidal range. The Mondego estuary presented a total of 85 different taxa during the study period. In general, the number of species at the mouth station was always higher, especially in summer (max. 34 species) (Fig. 4). Regarding heterogeneity $\left(\mathrm{H}^{\prime}\right)$, higher values were also found at the mouth (max. 2.20). In addition, it was possible to recognize a decrease in heterogeneity values, from September to December, for stations $\mathrm{M}$ and $\mathrm{S} 1$ at low tide and $\mathrm{S} 2$, at both tides. Nevertheless, that decrease was not followed by a decrease in the number of species. This was due to the dominance of an estuarine specie Acartia 
High tide
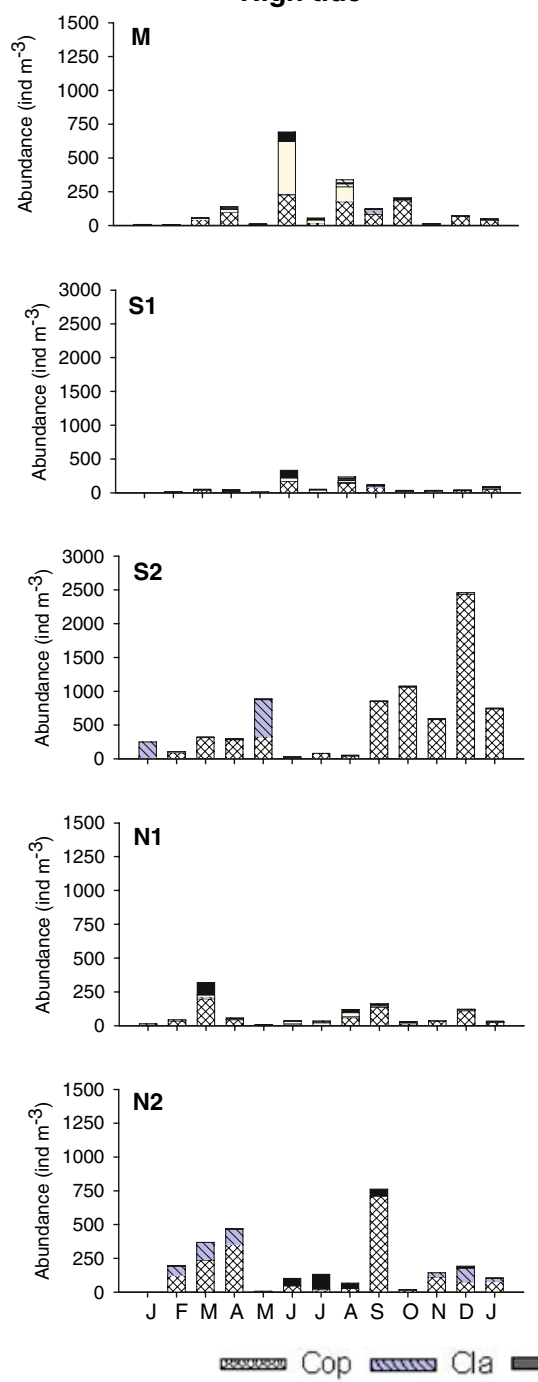

Low tide
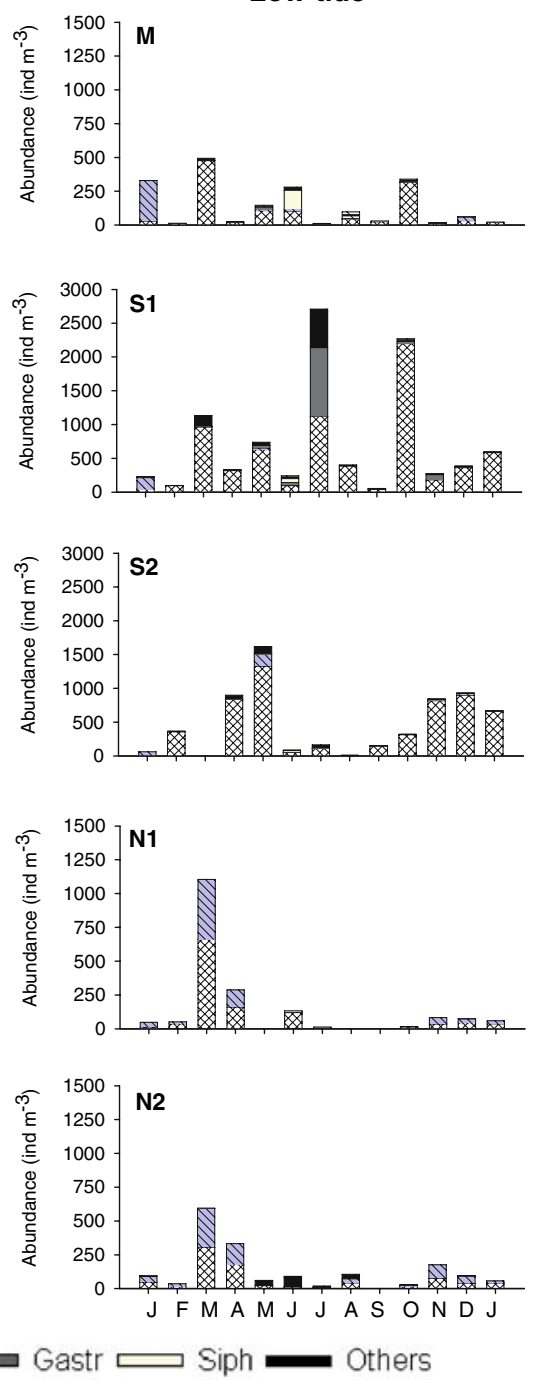

Fig. 3 Annual cycle of abundance (in $\mathrm{dm}^{-3}$ ) by major taxonomic groups of total zooplankton, at high tide and low tide, at the five sampling station. Gastr, Gastropoda, Siph, Siphonophora, Cop, Copepoda and Clad, Cladocera

tonsa Dana, 1,848. A similar pattern was also observed for the northern branch stations, during the summer months at low tide, due to higher densities of decapods larvae during this period. Zooplanktonic biomass, estimated only at high tide due to problems with suspended material at low tide, varied widely between all stations (Fig. 5). The highest biomass values were generally recorded at southern branch stations. As for zooplankton abundance the holoplanktonic forms were the most abundant. Among the holoplankton the copepods were the most abundant group (see Fig. 3) averaging 67.0\%, at both high and low tide, followed by Cladocera and Siphonophora. The dominant groups of meroplankton were Hydromedusae, Cirripedia larvae, Decapoda larvae and Gastropoda larvae. Table 1 contains the data obtained for the main zooplankton taxa found during the present study at the five stations, with their respective percentage of occurrence (\%). Five copepod genera contributed to $98 \%$ of the total copepod abundance. Dominant copepod species were the calanoids, composed predominantly by the estuarine species $A$. tonsa, followed 
High tide
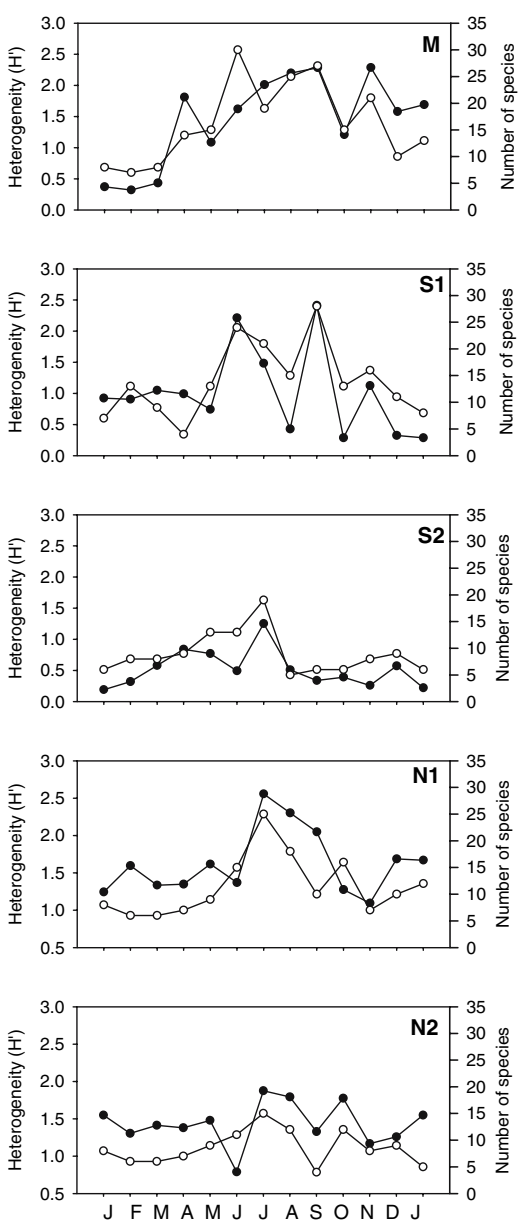

Low tide
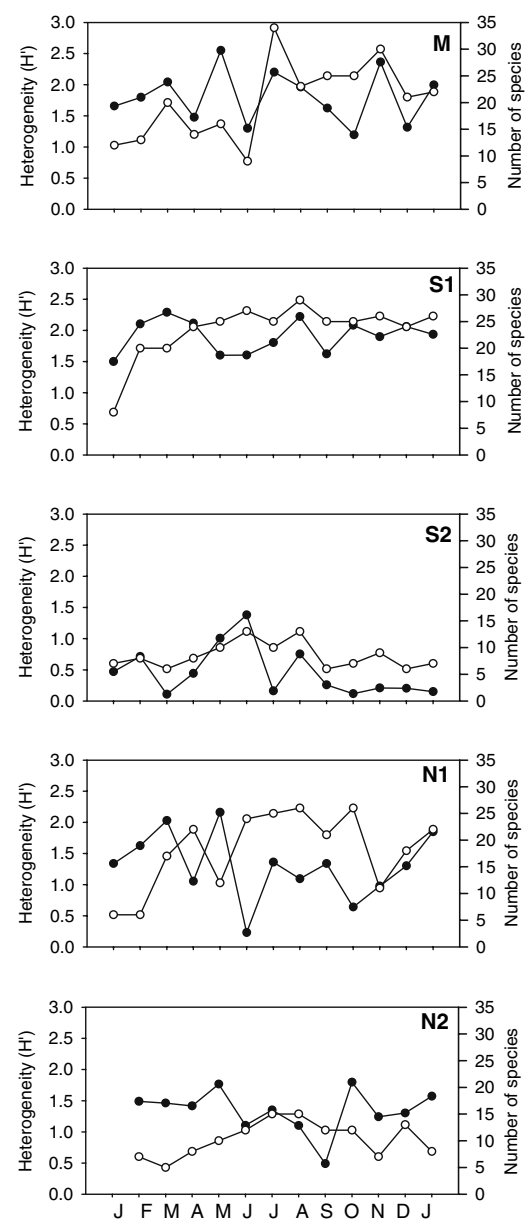

$-\mathrm{H}^{\prime} \rightarrow-$ Number of species

Fig. 4 Spatial and temporal variation of biodiversity based on number of species (open circles) and heterogeneity $\left(\mathrm{H}^{\prime}\right)$, Shannon-Wiener index (solid circles)

by marine neritic species like Acartia clausi Giesbrecht, 1889, Temora longicornis (Müller, 1792) and Paracalanus parvus (Claus, 1863), and by the freshwater copepod Diaptomus spp. (Table 1, Fig. 6). A. tonsa was the most important contributor to the copepod community, especially in the brackish zone, and reached greatest abundance in the southern branch of the Mondego estuary (max: 2,372 ind $\mathrm{m}^{-3}$ ). The Cladocera were mostly present in the upstream stations, especially in the northern branch, and the dominant genera were Daphnia longispina Müller 1763, Ceridaphnia spp. and Bosmina spp. Other genera like Podon and Evadne, appeared associated with downstream stations, during spring and summer, but in much lower abundance. Penilia avirostris Dana, 1852 appeared in higher abundance during late summer and autumn although, its contribution was small $(<3 \%$ of total Cladocera abundance). Siphonophora and Hydromedusae showed a summer distribution. The former was represented by the species Muggiaea atlantica Cunningham, 1892 and the Hydromedusae by Lizzia blondina Forbes, 1848 and Obelia spp. Decapoda larvae were only important in summer months and among them Rhithropanopeus harrisii (Gould, 1841) and Palaemon spp. dominated in the southern branch and Carcinus maenas (Linnaeus, 1758) appeared with higher abundance in the northern branch and mouth stations. 

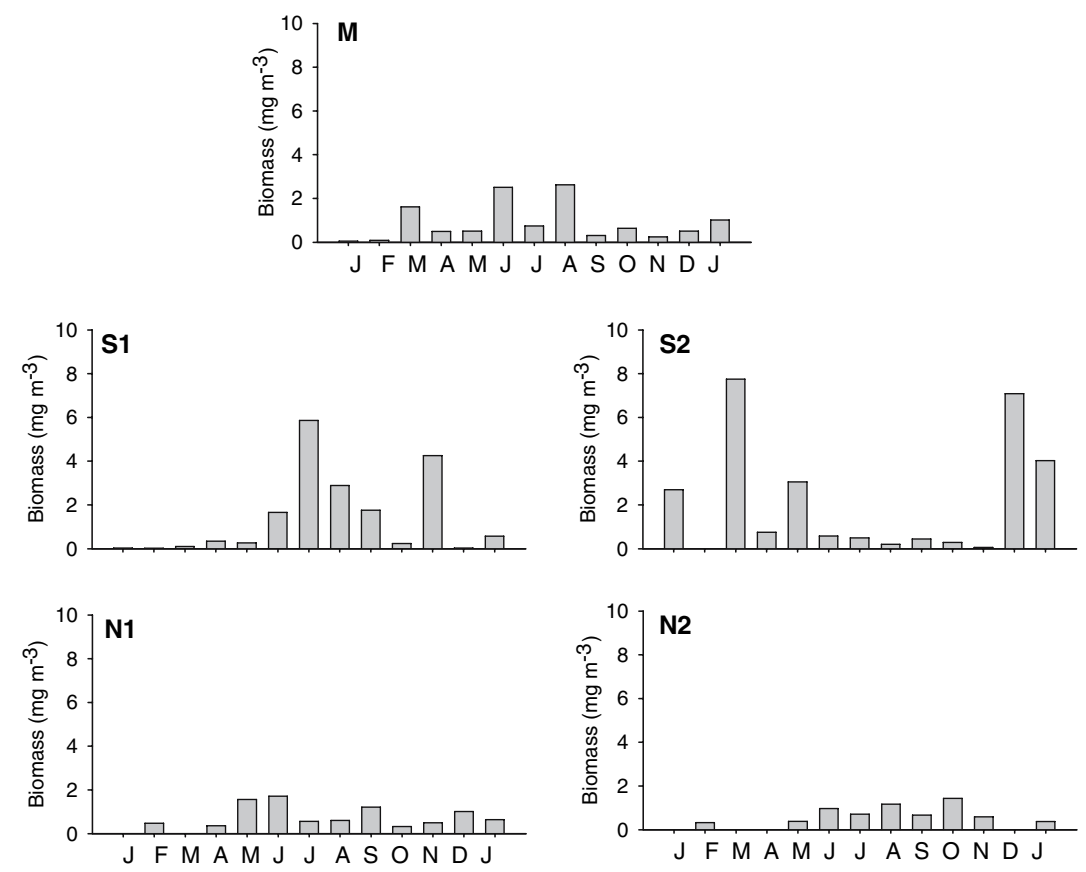

Fig. 5 Biomass $\left(\mathrm{mg} \mathrm{m}^{-3}\right)$ of total zooplankton at high tide, in each sampling station, during the study period

Table 1 Percentage occurrence (\%) for the main zooplankton groups

\begin{tabular}{|c|c|c|c|c|c|c|c|c|c|c|}
\hline & \multicolumn{2}{|c|}{ Station M } & \multicolumn{2}{|c|}{ Station S1 } & \multicolumn{2}{|c|}{ Station S2 } & \multicolumn{2}{|c|}{ Station N1 } & \multicolumn{2}{|c|}{ Station N2 } \\
\hline & HT & $\mathrm{LT}$ & HT & LT & HT & LT & HT & LT & HT & LT \\
\hline Appendicularia & & & & & & & & & & \\
\hline $\begin{array}{l}\text { Oikopleura dioica } \\
\text { Cirripedia }\end{array}$ & 70 & 46 & 77 & 31 & 8 & - & 46 & 23 & - & - \\
\hline $\begin{array}{l}\text { Nauplii } \\
\text { Cladocera }\end{array}$ & 54 & 46 & 39 & 62 & 39 & 39 & 39 & 39 & 39 & - \\
\hline Freshwater cladocerans & 38 & 62 & 31 & 46 & 39 & 39 & 54 & 85 & 77 & 92 \\
\hline $\begin{array}{l}\text { Podon Leuckarti } \\
\text { Copepoda }\end{array}$ & 54 & 39 & 54 & 15 & - & 8 & 15 & - & 15 & - \\
\hline Acartia clausi & 100 & 62 & 100 & 31 & 8 & - & 77 & - & - & - \\
\hline Acartia tonsa & 54 & 77 & 62 & 85 & 92 & 77 & 46 & 46 & 46 & 39 \\
\hline Diaptomus spp. & 39 & 46 & 23 & 23 & 23 & 15 & 69 & 77 & 85 & 92 \\
\hline Paracalanus parvus & 85 & 39 & 77 & 31 & - & 8 & 39 & - & - & - \\
\hline $\begin{array}{l}\text { Temora longicornis } \\
\text { Gastropoda }\end{array}$ & 100 & 62 & 85 & 54 & 39 & 31 & 69 & 31 & 31 & 23 \\
\hline $\begin{array}{l}\text { Hydrobia ulvae } \\
\text { Hydromedusae }\end{array}$ & 77 & 69 & 92 & 92 & 54 & 54 & 77 & 54 & - & 39 \\
\hline Lizzia blondina & 39 & 23 & 46 & 15 & - & - & 31 & - & - & - \\
\hline $\begin{array}{l}\text { Obelia spp. } \\
\text { Siphonophora }\end{array}$ & 39 & 15 & 54 & - & - & - & 54 & - & - & - \\
\hline $\begin{array}{l}\text { Muggiaea atlantica } \\
\text { Isopoda }\end{array}$ & 77 & - & 69 & 23 & 8 & 23 & 69 & 23 & - & - \\
\hline $\begin{array}{l}\text { Paragnathia formica } \\
\text { Decapoda }\end{array}$ & 69 & - & 92 & 77 & 77 & 62 & 62 & 62 & 54 & 46 \\
\hline Rhitropanopeus harrissi & 15 & - & - & 31 & 23 & - & 23 & - & 31 & - \\
\hline Palaemon spp. & 39 & - & 46 & 23 & - & 23 & 54 & 23 & 46 & 39 \\
\hline Zoeae Carcinus maenas & 77 & - & 85 & 31 & 31 & - & 62 & - & - & - \\
\hline
\end{tabular}

HT, high tide; LT, low tide 
HighTide

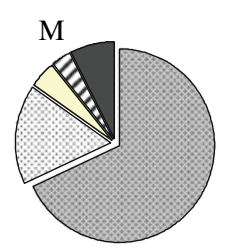

图Acartia clausi

Temora longicornis

$\square$ Paracalanus parvus

ZClausocalanus arcuicornis

$\square$ Others
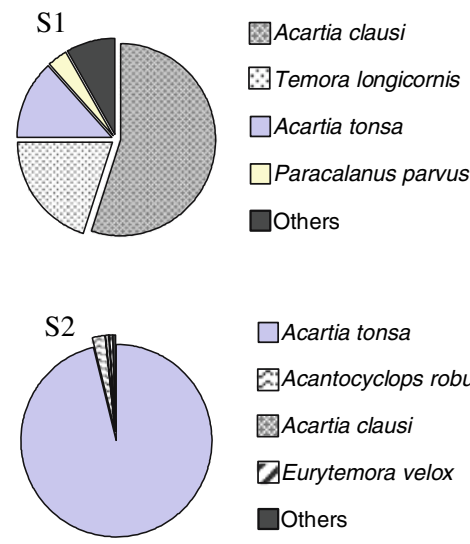

$\square$ Acartia tonsa

园Acantocyclops robustus

图Acartia clausi

DEurytemora velox

$\square$ Others

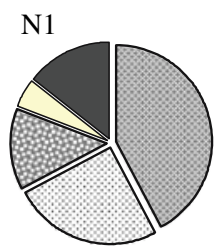

Acartia clausi

Temora longicornis

圆Diaptomus spp.

$\square$ Paracalanus parvus

$\square$ Others

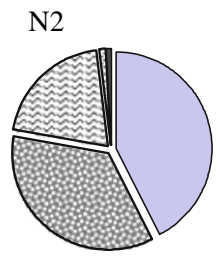

Low Tide

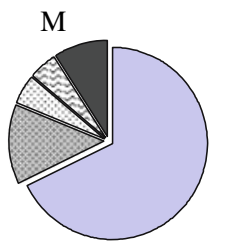

$\square$ Acartia tonsa

图Acartia clausi

Temoralongicornis

AAcantocyclops robustus

$\square$ Others

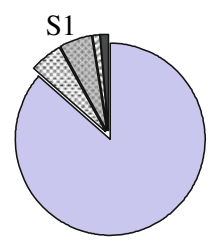

Acartia tonsa

图Calanipedia aquaeducis

Acartia clausi

Acantocyclops robustus

Dothers

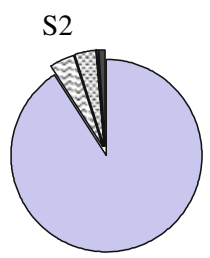

$\square$ Acartia tonsa

Acantocyclops robustus

圈Calanipedia aquaeducis

Diaptomus spp.

Dothers

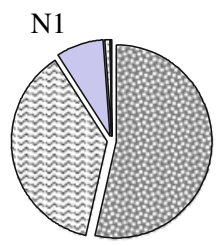

国Diaptomus spp.

Acantocyclops robustus

$\square$ Acartia tonsa

Temora longicornis

$\square$ Others

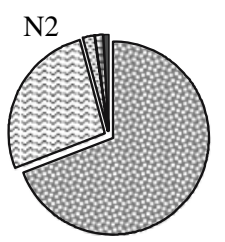

图Diaptomus spp.

$\checkmark$ Acantocyclops robustus

圆Calanipedia aquaeducis

田Copepodite n.id.

$\square$ Others

Fig. 6 Relative contribution (\%) of the four most abundant copepod species, at the five sampling station, at high tide and low tide, during the study period

Appendicularia were present mostly in downstream stations and the dominant species was Oikopleura dioica Fol, 1872.

Multivariate analysis of the zooplankton assemblages

The MDS plot shows that zooplankton communities of the five sampling stations are spatially separated distinguishing three assemblages of species-sites (Fig. 7). It is possible to observe a separation of the two upstream stations (N2 and S2), that accounted for species from freshwater environments. The intermediate stations $\mathrm{N} 1$ and S1 were more similar in taxonomic composition than any other station, due to an important intrusion of marine water in both stations. It is possible to distinguish the mouth station due to its high number of marine species. 
Fig. 7 Two-dimensional MDS ordination plot of zooplanktonic

communities. M, mouth station; S1 and S2, southern branch stations; $\mathrm{N} 1$ and N2, northern branch stations; sp, spring; su, summer; aut, autumn; w, winter

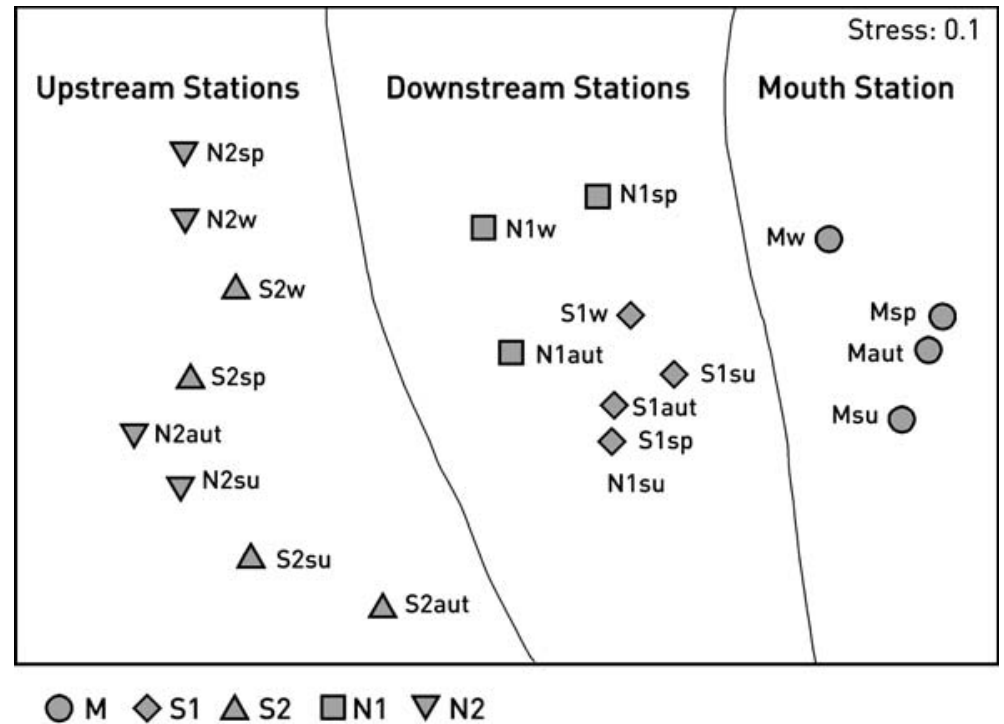

\section{Discussion}

The well defined spatial salinity gradient revealed by the PCA is a common feature of temperate estuaries resulting in a pronounced spatial effect on the zooplankton composition (Mouny \& Dauvin, 2002; Tackx, et al., 2004). Other factor, such as temperature may also be important in determining the seasonality of zooplankton species composition. This is in agreement with other studies (Azeiteiro et al., 1999; Calbet et al., 2001). Coastal systems in temperate zones frequently exhibit spatial-temporal gradients, both in environmental variables and plankton assemblages, because of their tight physical-biological coupling.

Unlike neritic and oceanic areas, where the peaks of zooplankton abundance are well defined and easily recognised (Calbet et al., 2001; Fernández de Puelles et al., 2003; Gilabert, 2001; Siokou-Frangou, 1996), in estuaries there is a lack of seasonality in zooplankton abundance throughout the year. The monthly fluctuations in zooplankton abundance may be a result of the combination of populations of different components, each with a specific, but often contrasting, seasonal pattern. In addition, the interaction of seawater and river flow can mask the seasonal zooplankton pattern by introducing a superimposed variability reflecting the complex response of zooplankton to the biological and environment conditions. Major differences in zooplankton abundance were apparent between station groups, being generally higher within the southern branch stations. Such differences may be related to the different hydrological characteristics of the two branches. The northern branch where dredging takes place regularly, exhibits lower residence time and environmental conditions are characterised by stronger daily changes in salinity. On the contrary, the stability of the water mass of the southern branch due to the low hydrodynamics and shallow depth associated with smaller daily salinity changes enhance higher zooplankton abundance, namely in the inner areas. Hence, the particular characteristics of the two branches allow us to consider them as two subsystems.

Total zooplankton abundance reflected quite well the seasonal variation of the copepods population. Indeed, the copepods dominated at all stations throughout the year. A decrease was observed only during the summer due to the higher abundance of copepod predator, such as Siphonophora and Hydromedusae (Azeiteiro et al., 1999; Vieira et al., 2003). The results also agree with findings in other areas, which showed that copepods usually constitute the main taxa (Calbet et al., 2001; Dalal \& Goswami, 2001; Fernández de Puelles et al., 2003; Gaudy, 2003). From the quantitative point of view, the most representative 
taxon was Acartia tonsa, which is typical for estuarine environments and may reach very high abundances in waters containing high concentration of particulate organic matter (Tackx et al., 2004; Murrel \& Lores, 2004). A. tonsa is currently dominant in the inner areas of the southern branch where the eutrophication is still more severe (Cardoso et al., 2004; Pardal et al., 2004).

Concerning biodiversity, heterogeneity values proved to be high in summer at downstream sampling stations because of the great contribution of marine species that invaded the estuary. The decrease in heterogeneity verified for the southern branch and mouth, especially at low tide, during autumn was not due to a decrease in the number of species but a dominance of the estuarine species $A$. tonsa whose reproduction period is in September. A similar pattern was also found in the Seine estuary (Mouny \& Dauvin 2002). In the northern branch the observed decrease in heterogeneity during the summer period was due to the higher abundance of decapods larvae. Many planktonic larvae, one of the most important components of the meroplankton, showed a clear seasonal trend related to temperature (Gilabert, 2001).

In addition, this work represents the first description of the zooplankton community of the northern branch of Mondego estuary and its comparison with the southern branch. Overall the MDS ordination and the PCA analysis results reinforce the idea that the zooplanktonic community of Mondego estuary is strongly influenced by humans either directly or indirectly and by the hydrological circulation patterns that occur in each arm. The northern branch is dominated by the river flow as a result of a direct human impact (e.g. suffering from regular dredging activities). The southern branch, a calmer and shallower channel is dominated by the tidal circulation that coupled with the nutrient enrichment of the waters origins an ongoing eutrophication process that is more severe in the upstream areas (Cardoso et al., 2004; Pardal et al., 2004).

Acknowledgement The present study was carried out in the scope of the research project Typology and Reference Conditions for Transitional and Coastal Portuguese Waters - TICOR, funded by INAG - Instituto da Água (Portugal). A special thanks to all our colleagues that helped during field work and two anonymous reviewers for their helpful suggestions on early version of the manuscript.

\section{References}

Azeiteiro, U. M. M., J. C. Marques \& P. Ré, 1999. Zooplankton annual cycle in the Mondego river estuary (Portugal). Arquivos do Museu Bocage, Nova Série 3: 239-263.

Bourdillion, A., 1964. Quelques aspects du probléme de ĺechantillonnage du plancton marin. Terre et la Vie 1: 77-93.

Calbet, A., S. Garrido, E. Saiz, M. Alcaraz \& C. M. Duarte, 2001. Annual zooplankton succession in coastal NW Mediterranean waters: the importance of the smaller size fraction. Journal of Plankton Research 23: 319-331.

Cardoso, P. G. M., M. A. Pardal, A. I. Lilleb $\varnothing$, S. M. Ferreira, D. Raffaelli \& J. C. Marques, 2004. Dynamics change in seagrass assemblages under eutrophication and implication for recovery. Journal of Experimental Marine Biology and Ecology 302: 233-248.

Clarke, K. R. \& R. N. Gorley, 2001. Primer v5: User Manual/Tutorial. Primer-E, Plymouth.

Clarke, K. R. \& R. M. Warwick, 2001. Change in Marine Communities. An Approach to Statistical Analyses and Interpretation, 2nd edn. Primer-E, Plymouth.

Dalal, S. G. \& S. C. Goswami, 2001. Temporal and ephemeral variations in copepod community in the estuaries of Mandovi and Zuari-West coast of India. Journal of Plankton Research 23: 19-26.

De Jonge, V. N., M. Elliot \& E. Orive, 2002. Causes, historical development, effects and future challenges of a common environmental problem: eutrophication. Hydrobiologia 475-476: 1-19.

Fernández de Puelles, M. L., J.-M. Pinot \& J. Valencia, 2003. Seasonal and interannual variability of zooplankton community in waters off Mallorca island (Balearic Sea, Western Mediterranean): 1994-1999. Oceanologica Acta 26: 673-686.

Gaudy, R., F. Youssara, F. Diaz \& P. Raimbault, 2003. Biomass, metabolism and nutrition of zooplankton in the Gulf of Lions (NW Mediterranean). Oceanologica Acta 26: 357-372.

Gilabert, J., 2001. Seasonal plankton dynamics in a Mediterranean hypersaline coastal lagoon: the Mar Menor. Journal of Plankton Research 23: 207-217.

Gonçalves, F., R. Ribeiro \& A. M. V. M. Soares, 2003. Comparison between two lunar situations on emission and larval transport of decapod larvae in the Mondego estuary (Portugal). Acta Oecologica 24S: S183-S190.

Kennish, M. J., 1990. Ecology of Estuaries. Vol. II. Biological Aspects. CRC Press, Ann Arbor.

Marques, J. C., M. A. Graça \& M. A. Pardal, 2002. Introducing the Mondego river basin. In Pardal, M. A., J. C. Marques \& M. A. Graça (eds), Aquatic Ecology of the Mondego River Basin. Global Importance of Local Experience. Imprensa da Universidade de Coimbra, Coimbra, 7-12. 
Mouny, P. \& J.-C. Dauvin, 2002. Environmental control of mesozooplankton community structure in Seine estuary (English Channel). Oceanologica Acta 25: 1322.

Murrel, M. C. \& E. M. Lores, 2004. Phytoplankton and zooplankton seasonal dynamics in a subtropical estuary: importance of cyanobacteria. Journal of Plankton Research 26: 371-382.

Nedwell, D. B. \& D. G. Raffaelli, 1999. Estuaries. Advances in Ecological Research 29. Academic Press, London.

Omori, M. \& T. Ikeda, 1984. Methods in Marine Zooplankton Ecology. Wiley-Interscience, New York.

Pardal, M. A., P. G. Cardoso, J. P. Sousa, J. C. Marques \& D. Raffaelli, 2004. Assessing environmental quality: a novel approach. Marine Ecology Progress Series 267: $1-8$.

Pardal, M. A., J. C. Marques, I. Metelo, A. I. Lillebø \& M. R. Flindt, 2000. Impact of eutrophication on the life cycle, population dynamics and production of $\mathrm{Am}$ pithoe valida (Amphipoda) along an estuarine spatial gradient (Mondego estuary, Portugal). Marine Ecology Progress Series 196: 207-219.

Siokou-Frangou, I., 1996. Zooplankton annual cycle in a Mediterranean coastal area. Journal of Plankton Research 18: 203-223.
Tackx, M. L. M., D. P. Nathalie, V. M. Riet, F. Azémar, H. Abdelhacq, V. D. Stefan, F. Frank, D. Nanette \& M. Patrick, 2004. Zooplankton in the Schelde estuary, Belgium and The Netherlands. Spatial and temporal pattern. Journal of Plankton Research 26: 133-141.

Ter Braak, C., 1995. Ordination. In Jongman, R. H. G., C. J. F. ter Bterraak \& O. F. R. Tongeren (eds), Data Analysis in Community and Landscape Ecology. Cambridge University Press, Cambridge, 91-173.

Ter Braak, C. J. F. \& P. Smilauer, 1998. CANOCO Reference Manual and User's Guide to Canoco for Windows: Software for Canonical Community Ordination (version 4). Microcomputer Power, Ithaca, New York.

Vieira, L., U. M. Azeiteiro, P. Ré, R. Pastorinho, J. C. Marques \& F. Morgado, 2003. Zooplankton distribution in a temperate estuary (Mondego estuary Southern arm: Western Portugal). Acta Oecologica 24S: S163-S173.

Zar, J. H., 1996. Biostatistical Analysis. Prentice-Hall International, London. 